\title{
Grundtvigs udfordring til moderne theologi
}

\author{
Af Regin Prenter
}

Det er yderst vanskeligt for ikke at sige umuligt at tegne et nogenlunde sammenhængende og éntydigt billede af moderne theologi.

Theologien omfatter i dag en række såkaldte »discipliner «, som stort set arbejder uafhængigt af hverandre: eksegetisk, historisk, systematisk og praktisk theologi. Det gør billedet af moderne theologi nok så kompliceret.

Dertil kommer, at det theologiske arbejde præges af forskellige modstridende tendenser tildels som følge af nationale, sproglige og konfessionelle traditioners indflydelse. Nutidig romersk-katholsk, orthodoks, luthersk og anden protestantisk theologi følger vidt forskellige veje, selv om de tager udgangspunktet i de samme grundspørgsmål. Tysk, amerikansk og skandinavisk luthersk theologi frembyder tre klart forskellige variationer af samme konfessionelle arv.

Endelig finder vi inden for samtlige konfessioner og traditioner stridende retninger og skoler, hvad der yderligere forvirrer billedet af moderne theologi. Det vil f.eks. være umuligt at bringe nutidig eksistentialistisk og fundamentalistisk theologi inden for samme nationale eller konfessionelle sammenhæng på én formel.

Men hvordan skal man så tale om Grundtvigs udfordring til "moderne theologi«?

Billedet af moderne theologi må stærkt forenkles, før man kan stille den over for Grundtvigs udfordring.

$\mathrm{Da}$ Grundtvig var luthersk, er det rimeligt at begrænse sig til moderne protestantisk theologi, selv om det patristiske indslag $i$ Grundtvigs theologi på mange måder nærmer ham til visse former af moderne romersk-katholsk og orthodoks theologi. 
Videre må vi indskrænke os til at behandle systematisk theologi i videste forstand.

Og endelig må vi nøjes med at pege på fremherskende tendenser $\mathrm{i}$ det nutidige systematisk-theologiske arbejde. Vi kan ikke drøfte enkelte theologer og deres specielle idéer.

I de to årtier mellem første og anden verdenskrig gennemløb protestantisk systematisk theologi en dybtgående fornyelse. Førende theologer, hvis ubestridte førstemand var Karl Barth, vendte sig bort fra det 19. århundredes såkaldte "liberale « theologi med dens optimistiske rationalisme og dermed fra forsøget på at underordne Guds åbenbaring under menneskets religion og Kristi kirke under den moderne kultur for $\mathrm{i}$ stedet for alt dette at opbygge en ægte åbenbaringstheologi eller, som man oftest sagde, en »Guds ords theologi«, der, som i Barths tilfælde, kunne udvikles til en »kirkelig dogmatik«.

Denne theologiske omvæltning medførte en voksende interesse ikke blot for bibelsk theologi, men også for studiet af kristen tænknings store klassikere, kirkefædrene, de middelalderlige skolastikere og - frem for alt - det 16. århundredes reformatorer, som i særlig grad påvirkede disse "neo-orthodokse « theologers tænkning. Sådan kaldte man senere disse theologer i U.S.A.

I dag præges den theologiske scene af en næsten altomfattende og tildels voldsom reaktion fra den unge generations side mod den theologiske fornyelse, som fandt sted i tiden mellem de to verdenskrige.

I 1960'erne og 70'erne ændres det theologiske klima hurtigt og måske på en mere afgørende måde end $i$ årene straks efter første verdenskrig. Ikke sådan at forstå, at unge theologer af i dag drømmer om at vende tilbage til århundredskiftets liberale theologi, selv om de er rede til at anerkende dens kritiske holdning til den kristne klassiske arv. Århundredskiftets theologiske liberalisme var fra inderst til yderst borgerlig, i en vis grad endog "preussisk " borgerlig. I dag er yngre theologer - hvis man ser bort fra »fundamentalisterne « - næsten uden undtagelse socialister og yderst kritiske mod Vestens »etablerede « kapitalistiske samfund.

Kunne man betegne mellemkrigstidens herskende theologi som en »ordets theologi«, ser det ud som om nutidig theologi mere og mere udvikler sig til en »verdens theologi«. »Verden« står i midt- 
punktet af nutidige theologers interesse. Det theologiske hovedspørgsmål lyder ikke længer, som i mellemkrigstiden: »Hvad siger Skriften? « eller: "Hvad siger kirkens bekendelse? " om det eller det spørgsmål, men: »Hvad kan eller skal kirken, resp. de kristne, gøre for at forandre verden, så den bliver et bedre sted at leve for de sultne og undertrykte mennesker, der endnu udgør menneskehedens store flertal? «

Under indflydelse fra ny-marxistiske tænkere som f.eks. Ernst Bloch bliver politisk aktion i stigende grad gjort til kriterium for theologisk sandhed, f.eks. i Jürgen Moltmanns revolutionstheologi. ${ }^{1}$ Det er ikke ensbetydende med, at de pågældende theologer tager afstand fra "åbenbaringstheologien « som sådan. Nogle af dem, som f.eks. Jürgen Moltmann, er Barthdisciple og ønsker at drive en »ordets theologi «. Men de er overbevist om, at al sandhed, altså også Guds åbenbarings sandhed, ikke erkendes som sådan, med mindre den omsættes $\mathrm{i}$ handling, d.v.s. politisk aktion. $\mathrm{Og}-$ dette er typisk for en indflydelsesrig theolog som Moltmann evangeliets sandhed bliver en politisk drivkraft i samme grad som det forkynder frelse som genstand for håb. Bibelsk eskatologi og nymarxistisk håbsfilosofi (Ernst Bloch) smelter sammen til ét i Moltmanns »håbets theologi«. Det kristne håb om en eskatologisk frelse for hele universet, forvandles til sentimental snak, hvis det ikke udløser en politisk handlen med det formål at forandre verden her og nu, gøre den mere menneskelig. Mennésker håber ikke i sandhed på en evig frelse, hvis de ikke aktivt arbejder for deres medmenneskers jordiske frelse (»shalom «, et af tidens mest yndede slagord).

Men hvis politisk aktion skal være kriterium for theologisk sandhed, må theologisk sandhed åbenbart kunne oversættes til politisk program. Men er der så plads for en levende Gud? Bliver spørgsmålet om Gud ikke betydningsløst i sammenligning med planerne for verdens forandring? Eller er "Gud « et ord, der kun rummer virkelighed i sig, når det optræder $\mathrm{i}$ et politisk programs sammenhæng? Er »theismens « gudsforestilling andet og mere end en skabelse af den religiøse fantasi? Bliver det ikke nødvendigt at forla-

1. Jürgen Moltmann: Gott in der Revolution, i: Diskussion zur "Theologie der Revolution «, eingeleitet und herausgegeben von Ernst Feil und Rudolf Weth, München 1969, s. 65-81, især these 4: Das neue Kriterium der Theologie und des Glaubens liegt in der Praxis, s. 73-75. 
de ikke blot "kirken « (som en integrerende del af det »etablerede« samfund), der må falde, hvis ægte menneskelighed skal fremmes, men også tanken om en personlig Gud? Er ikke theismen under enhver form uløseligt forbundet med den »etablerede« kirke $\mathrm{i}$ det "etablerede« samfund, sådan at frem for alt den må falde, hvis verden skal radikalt ændres? Det er fuldt ud forståeligt, at yderliggående former af »verdens theologi« sommetider bliver »atheistisk « kristendom, en »Gud-er-død-theologi« eller en kristocentrisk theologi, hvori mennesket Jesus ikke åbenbarer Gud, men træder i stedet for ham (som i Dorothee Sölles theologi).

Naturligvis er det langt fra alle theologer, der ligger på den her angivne linie, som vil drage så radikale konsekvenser af ansatsen. Alligevel er jeg overbevist om, at det er de mest yderliggående og ikke de utallige forsøg på kompromis mellem "politisk theologi« og »åbenbaringstheologi« - former af »verdens theologi« (sækulartheologien), der viser, i hvilken desperat situation politisk engagerede unge theologer i dag befinder sig. Bibelens og bekendelsens »Gud « og denne Guds »ord « og verdens krav på forandring og denne forandrings målsætning i den revolutionære socialisme lader sig ikke uden videre sammensmelte. Jo radikalere der tænkes i begge retninger, des mere trænger et uigenkaldeligt valg mellem Gud og verden, mellem Bibelen og marxismen sig på.

Jesu ord: "I kan ikke tjene Gud og Mammon« lader sig uden stor vanskelighed omskrive til: »I kan ikke elske den lidende verden og kirkens Gud «.

I dag trænger den lidende verden fortvivlet til gode mænds og kvinders aktive kærlighed. Gud - om han ellers er til - kan - om han er Gud - klare sig uden menneskers tro og kærlighed; men mennesker kan ikke klare sig uden deres medmenneskers tillid og kærlighed. Hvis theologi er kristne menneskers forsøg på at klare sig, hvad det vil sige at være kristen, og hvis det at være kristen på en eller anden måde er at være forpligtet på den menneskekærlighed, der kommer til syne i Jesu omgang med mennesker, som den er skildret $\mathrm{i}$ evangelierne, synes kristne at blive drevet til en revision af deres hele theologi, sådan at den troskab og kærlighed, som i den gamle theologi Gud gjorde krav på, nu overføres til den lidende verdens mennesker.

Men hvordan vil en sådan revision kunne gennemføres, uden at troen på en levende Gud opgives? Bliver vi i en sådan revision ikke 
nødt til at tolke kristendommen som menneskekærlighedens princip, forkyndt og illustreret af Jesus, som kaldtes Kristus, og dermed opgive alle de traditionelle dogmer, ja, selve forestillingen om en levende Gud? Er en sådan »anti-theistisk « (»a-theistisk «?) tolkning af evangeliet den eneste skikkelse, hvori kristendommen kan overleve?

Det er til theologer, for hvem spørgsmål af denne art er uafviselige, Grundtvig er en udfordring.

Grundtvig er uden tvivl den største theolog, der har skrevet på dansk, selv om han ikke producerede akademisk theologi af den sædvanlige slags. Han var ikke doktor $\mathrm{i}$ theologien og blev aldrig theologisk professor. Men hans salmer, hans prædikener, hans historiske og mythologiske skrifter er fyldt til randen med theologi af højeste karat.

På den anden side var han en udpræget "verdslig « forfatter målt med de sædvanlige theologiske målestokke: digter, filosof det var han nemlig, så det battede! - pædagog, historiker, politiker. Men han var ikke fysiker, ikke biolog, ikke økonom, hvad det nu så ellers måtte betyde.

Det pudsige ved Grundtvig er nu, at det aldrig lykkes ham at holde de enkelte sider af hans mangesidede virke ordentligt ude fra hinanden. Han var ikke »systematiker«. Hans verdslige engagement er allestedsnærværende $\mathrm{i}$ hans theologi som urovækker og igangsætter. Hans theologi er på tilsvarende måde allestedsnærværende $\mathrm{i}$ hans verdslige tænkning og handlen som forudsætning og grænse. Men aldrig sammenblander han det kristelige og det verdslige. De to »engagementer « - for at tale udansk og ugrundtvigsk, men »nutidigt« - holdes sammen i hans levende person, men sondres i hans redelige tanke. Det er denne ejendommelighed ved Grundtvig som theolog, der gør ham til en udfordring til moderne theologi.

Det er umuligt at bringe Grundtvigs theologi til udtryk i en enkelt "grundtanke« - så ofte det iøvrigt er blevet forsøgt. Men ikke destomindre kan man pege på nogle tydelige drivkræfter $i$ hans theologiske tankegang. Vi kan - med forsigtighed - udtrykke dem i to berømte og ofte citerede udsagn fra hans digtning 
Kun ved badet og ved bordet

hører vi Guds ord til os.

Menneske først og kristen så, det er et hovedstykke.

De første to verselinier sammenfatter Grundtvigs så ofte diskuterede og af theologer næsten énstemmigt kritiserede "kirkelige anskuelse«. Kirken er et åndeligt gudsfolk, samlet omkring døbefont og nadverbord. Dér alene - altså hvor døbefonten og nadverbordet står og er i brug - hører vi Guds ord - til os! »Til os« vil sige: til os som Guds folk! Der er i denne kirkeopfattelse, når den sammenlignes med den moderne sækulartheologis tale om »kirken « (»kirke for verden« o.s.v.), en påfaldende eksklusivitet. Cyprians »Uden for kirken ingen frelse!« synes at blegne i sammenligning med Grundtvigs »kun ved badet og ved bordet«. Ordet, der lyder ved døbefont og nadverbord, og menigheden som Guds åndelige folk er i Grundtvigs theologi korrelater. Kun hvor den ene størrelse er, er den anden også! Kun i menigheden, i Guds folk, ved dets gudstjeneste med de indstiftelser, dens Herre gav den, taler Gud til sit folk. Omvendt: kun hvor Gud selv taler - og når han selv taler, når dåb og når nadver fejres! - er der menighed til. Kirken, som Grundtvig forstår den, er ikke »verden«, ikke en del af verden. Og verden, som Grundtvig opfatter den, er ikke kirke, ikke engang potentielt. Aldrig kunne Grundtvig - efter sin »mageløse opdagelse « af denne sammenhæng mellem ordet og kirken - falde til ro i de gamle statskirkelige tankebaner, at Guds folk blot er den jordiske nation organiseret til sin gudsdyrkelse. Heller ikke ville han - som endnu vor salmebogs bønneafsnit - kunne kalde det danske folk et kristent folk. Kirken er et åndeligt gudsfolk af alle folk og tungemål. Der var kun ét jordisk gudsfolk - Israel!

Døbefonten og nadverbordet findes inde i kirkehuset. Derin$d e(!)$ taler Gud alene til sit folk, ikke derude - i verden, i »det politiske rum «, hvor de politiske theologer lytter efter hans røst.

Grundtvigs »kirkelighed « gør Grundtvig til en »katholsk« - i oldkirkelig og engelsk betydning af ordet - theolog, men hverken romersk- eller græsk-katholsk! Alligevel er Grundtvigs »katholicisme " udpræget luthersk, og med rette betragtede Grundtvig altid sig selv som ægte lutheraner. Thi for Grundtvig er både døbe- 
font og alterbord steder, hvor Gud taler til sit folk. Alene Guds talte ord giver mennesket liv. Og Gud har selv valgt, hvor og hvordan han vil tale sit livsskabende ord til dødelige mennesker. Begge tanker er grundlutherske.

Hvor som helst Gud selv taler sit ord til mennesker på den måde, han selv har valgt at gøre det, og dette ord af de mennesker, det tales til, høres, troes og bekendes, dér er Guds folk som et levende, åndeligt fællesskab midt $\mathrm{i}$ en jordisk nation, levende sit eget genfødte, åndelige, evige liv, som er tro, håb og kærlighed, givende sig selv til kende i troens, håbets og kærlighedens sprog, i livstegnene bekendelse, forkyndelse og lovsang.

Hvorfor denne kirkelige eksklusivitet? Hvorfor binder Grundtvig Guds ord til kirkens sakramenter, dåb og nadver?

Der kan gives to svar på det spørgsmål.

1) Guds livsskabende ord er Jesus Kristus selv. For Grundtvig er dåben den nye pagt mellem Gud og hans folk, Gud og den faldne menneskeslægt, hvilende på Guds skaber- og genløserværk i og ved hans eenbårne Søn. Derfor sker dåben i den treenige Guds navn, Faderens, Sønnens og Helligåndens navn. Ingen anden end den treenige Gud selv kan sige, hvad det navn rummer. Og det gør han, når dåben finder sted, i dåbspagtens ord, den apostoliske trosbekendelse, forstået som Guds egen tolkning af sit navn i og ved den skabelsens og genløsningens historie, hvis begivenheder sammenfattes i dåbspagtens (trosbekendelsens) tre artikler, og hvis midtpunkt udgøres af Jesu fødsel, liv, død, opstandelse, himmelfart og komme til dom. Når dåbspagtens ord tages efter pålydende, er der ikke tale om nogen »kirkelig « snæverhed. Vi er allerede ved dens første sætninger ført langt uden for kirkemurene i nævnelsen af himmelens og jordens og alle tings skabelse. Men det er $i$ kirken, ved døbefonten, Gud taler det ord, der tager os med ud i hans store univers.

I et spørgsmåls form (»Forsager du ...? Tror du ...?«) taler Gud ved døbefonten i dåbspagtens bestemte udtryk det ord, der tolker hans navns hemmelighed, som er Jesus Kristus selv. Gud Fader, alle tings skaber, er Jesu Kristi Fader. Jesus Kristus er Guds eenbårne Søn, Gud selv som vor broder, delende vort liv. Helligånden er énhedsbåndet mellem Gud Fader og Guds Søn, deres evige kærlighed, som i Sønnen også binder hans folk til Faderen. 
At Guds egen tolkning af sit navns hemmelighed lyder $\mathrm{i}$ et spørgsmåls form, er for Grundtvig af største vigtighed. (Derfor bliver der, så længe der i Danmark findes »rigtige « Grundtvigianere, krig i den danske folkekirke, hvis man prøver at afskaffe tilspørgslen ved dåben). Det betyder, at livet i dette navn, troen, ikke er menneskets egen mulighed eller valg, men helt igennem Guds gave, ja, gave i så absolut en forstand, at Gud også giver os selve den ordlyd, i hvilken vi siger ja til hans tilbud!

I nadveren er Guds ord til hans folk bundet til Jesu legemes og blods gaver, det er en »kærlighedserklæring «, hvormed Gud opretter den fulde enhed mellem sig og alle dem, der døbtes til hans treenige navn og $\mathrm{i}$ tro og troens bekendelse lever i det navn, ved Jesu ofrede legemes og blods gaver.

Guds livsskabende ord er Jesus Kristus selv. I den konsekvente fastholdelse af denne sandhed er Grundtvig »orthodoks « kristen i ordets strengeste forstand. Det er grunden til hans kristendoms kirkelige eksklusivitet: Guds ord er hos ham uløseligt bundet til dåben og nadveren i menighedens gudstjeneste.

2) Mennesket, skabt i Guds billede, mennesket, til hvem Gud taler sit livsskabende ord i Jesus Kristus, er en forunderlig blanding af ånd og kød, som Grundtvig siger det i den berømte indledning til »Nordens Mythologi«:... en mageløs, underfuld Skabning, i hvem Guddommelige Kræfter skal kundgiøre, udvikle og klare sig giennem tusinde Slægter, som et Guddommeligt Experiment, der viser, hvordan Aand og Støv kan giennemtrænge hinanden, og forklares i en fælles guddommelig Bevidsthed. «2

Det ord, Gud taler til dødelige mennesker i Jesus Kristus, er ikke et udtryk for tidløse sandheder i menneskelige begreber, men Guds egen evige sandhed, den sandhed Gud er, og som al anden sandhed kommer fra, blevet menneske og derfor et historisk ord. Jesus Kristus, Guds menneskeblevne sandhedsord, trædende ind $\mathbf{i}$ menneskers historie, må nødvendigvis blive et sakramentalt ord, d.v.s. et ord, der har et legeme, vandet $\mathrm{i}$ dåben, brødet og vinen $\mathrm{i}$ nadveren. På dette punkt er Grundtvig i dyb overensstemmelse med Martin Luther.

Ved at antage sig et legeme - $\mathrm{i}$ dåben og nadveren - bliver Guds livsskabende ord begivenhed, eller rettere: begivenheden,

2. Udvalgte Skrifter ved Holger Begtrup, V. S. 408. 
den afgørende begivenhed i hvert menneskes historie. Dåben er den nye fødsel ind i Guds rige, til et liv i Guds sandhed, og som enhver fødsel en uigentagelig engangsbegivenhed, begivenhed i ordets strengeste forstand.

$\mathrm{Og}$ nadveren er Gudsfællesskabets begivenhed: at foreningen mellem Gud og menneske i kærlighedens fuldkommenhed her og $\mathrm{nu}$, ved et nadverbord $\mathrm{i}$ en bestemt kirke en bestemt søndag, finder sted.

Som mennesket selv er et guddommeligt forsøg på at lade ånd og støv gennemtrænge hinanden igennem en årtusindlang slægtshistorie, sådan må Gud, når han i sit livsskabende ord i Jesus Kristus selv går ind i denne historie og giver den retning og fart, tale menneskeligt og historisk med historiske mennesker, d.v.s. lade sit ord få legeme og blive begivenhed i et sakramentes skikkelse.

\section{Ligned Legemet ej Aanden, Og ej Mennesket sin Gud, Spildt var da al Aabenbaring, Naadens Røst og Lovens Bud. ${ }^{3}$}

Grundtvigs »kirkelige anskuelse « er en kraftig udfordring til den moderne sækulartheologis stillen vor egen nødlidende og revolutionsmodne »verden « (= samfund) i centrum. Udfordringen ligger i Grundtvigs kirkelige orthodoksi.

Grundtvig stiller den moderne theologis socialistiske engagement ansigt til ansigt med den orthodoks kristne sondring mellem jordisk og evig frelse. Alle mennesker, rige og fattige, undertrykkere og undertrykte, uden forskel, lever under dødens herrevælde, fordi de alle, uden forskel, har vendt sig fra Gud, deres skaber og alt livs giver. Ingen revolution, ingen form for jordisk »frelse $i$

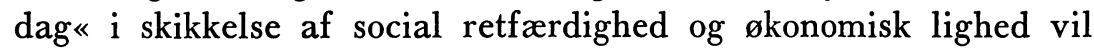
nogensinde kunne skænke et menneske evigt liv, frigørelse fra dødens herrevælde. Det fuldkomne menneskeliv, mennesket skabtes til som Guds afbillede at leve på jorden, kan ikke udfolde sig, hvor døden ikke er overvundet. Men i Kristus genfødes og oprejses dødelige menneskers liv til evighed, sådan at det som tro, håb og kærlighed til Kristus leves allerede her og nu - i menigheden,

3. Poetiske Skrifter, ved Svend Grundtvig og Georg Christensen, VIII, s. 492. 
hvor mennesket genfødes til evigt liv i dåben, og det genfødte liv næres i nadveren. Det er menneskets »kristelige, åndelige og evige liv $\ll .4$

Grundtvigs udfordring til moderne sækulartheologi er hans faste overbevisning, at menneskets jordiske velfærd, som disse theologer med rette er så optaget af, ikke er dets endelige livsmål. Mennesket blev skabt til evigt liv. Selv i det mest retfærdige af alle samfund, selv i den fuldkomne socialistiske stat (efter revolutionen!), kan mennesket ikke finde evigt liv uden for Kristus og hans folk, uden dåben og nadveren. Grundtvigs udfordrende spørgsmål til den moderne politisk (socialistisk) orienterede sækulartheologi er dette: Ofrer den ikke i den sociale revolutions interesse den kristne tro på Gud og på menneskets evige bestemmelse?

$\mathrm{Vi}$ vender os til det andet udsagn:

Menneske først og kristen så, det er et hovedstykke.

Her synes alt, hvad der hidtil er sagt, at blive vendt på hovedet. Hvis det er menneskets bestemmelse at leve et evigt liv, og hvis troens håbets og kærlighedens »kristelige, åndelige og evige liv" kun tilbydes mennesker i Jesus Kristus, Guds livsskabende ord i menneskeligt kød og blod, da synes det indlysende, at mennesket må blive »kristen først « for - som en følge heraf - at nå til det genfødte og i Kristus oprejste menneskeliv, der er hans medfødte menneskeliv i den fuldkommenhed, mennesket er bestemt til at leve det. »Kristen (genfødt) først, menneske (sandt, fuldkomment) menneske så!«

4. Disse tanker udvikles i afhandlingerne "Det kristelige, aandelige og evige Liv« og "Det medfødte og det gjenfødte Menneske-Liv« $i$ "Den kristelige Børnelærdom«, Udvalgte Skrifter ved Holger Begtrup, IX, S. 417-436, afhandlinger, der vidner om, hvor originale og dybtgående Grundtvigs theologiske tanker er. "... saa at Menneske-Livet $i$ sin allerdunkleste, sin allerfattigste og sin allerureneste Skikkelse dog i Grunden er af samme Art, som Menneske-Livet i sin allerrigeste, allerreneste og allerklareste Skikkelse, saa at $\vdash$ for at sige alt med eet Ord - Røveren paa Korset havde samme Menneske-Liv til fælles med Guds enbaarne Søn, Vorherre Jesus Kristus, til hvem han raabte: Herre! tænk paa mig, naar du kommer i dit Rige! (s. 429). 
Men dette er just, hvad Grundtvig ikke siger! Han siger det modsatte: menneske først - og kristen så!

Altså har man misforstået Grundtvig, hvis man opfatter hans kirkelige anskuelse sådan, at den skulle gå ud på, at der slet ikke findes sandt menneskeliv, hvor der ikke er kristen tro, håb og kærlighed.

Hvad Grundtvig siger, er rigtignok, at der ikke er nogen genløst menneskelighed, d.v.s. menneskelighed taget ind i et evigt fællesskab med Gud, uden i den kristne tro, håb og kærlighed, uden for kirken, uden dåb og nadver. Men det vil ikke sige, at mennesket ikke er sandt menneske, inden dets menneskeliv genfødes til evighed i Jesus Kristus. Det var just denne misforståelse, som middelalderlig katholicisme og luthersk orthodoksi var fælles om, Grundtvig lidenskabeligt bekæmpede, fra 1825 og hele sit liv derefter.

Ethvert menneske er som menneske Guds skabning og dermed sandt menneske. Hvis det ikke er tilfældet, kunne Guds evige Søn ikke blive menneske, og vi kunne ikke frelses fra dødens herrevælde til evigt liv ved at blive delagtiggjort i Guds Søns fuldkomne menneskeliv.

At mennesket er faldet, at det er en synder, som hverken har magt eller ret til at tilgive sig selv, at det er et dødeligt væsen, der ikke kan vinde sig selv et evigt liv, betyder ikke, at det i sin faldne stand, i sin syndighed og dødelighed, er ophørt med at være Guds skabning, skabt i Guds billede.

Tværtimod! Før Kristus, uden for kirken, uden sakramenterne, findes ægte skabt menneskelighed, som venter på sin forløsning fra synden og døden, ægte menneskelighed, som er skikket til at blive genløst og oprejst til evighed i Jesus Kristus, og som også i dens faldne, uigenløste, jordiske og dødelige skikkelse er og forbliver menneskelighed, hverken dyriskhed eller djævelskhed.

"Menneske først og kristen så « siger, at ingen kan blive kristen, d.v.s. tro på Gud og sin egen evige bestemmelse i Kristus, høre og fæste lid til Guds livsskabende ord i dåben og nadveren, åbne sit hjerte for troens, håbets og kærlighedens liv, uden først at være menneske, d.v.s. Guds skabning, skabt i hans billede.

Grundtvig hævder, at der er en banet vej, der fører fra ægte "medskabt « menneskelighed til »igenfødt« menneskelighed i Jesus Kristus. Ingen kan modtage sit menneskelivs oprejsning $i$ Je- 
sus Kristus uden forst at have vedkendt sig sin skabte menneskelighed $i$ faldet. Menneske først - kristen så!

Der går ingen vej fra fornægtelsen af vor skabte menneskelighed til dens frelse. Mennesker kan fornægte deres egen (og andres!) gudskabte menneskelighed på en sådan måde, at vejen til Kristus dermed spærres. Grundtvig, den »glade kristendoms« forkynder, har aldrig bestridt fortabelsens mulighed.

Men hvori består den sande, medskabte menneskelighed, som alle mennesker er fælles om, og som den, der skal blive kristen, først må vedkende sig? Grundtvigs svar på dette spørgsmål er klart og bestemt: talens gave!

Mennesket er hverken Fisk eller Fugl,

Kan dog baade svømme og sjunge, Han staar som en Gud i Dyrekreds

Med Ordet som Lyn paa sin Tunge.

Underligst og af alt paa Jord

Er Menneske-Røsten i Ørken, Med Ord om, hvad intet $\emptyset_{j}$ e saa, Men hvad dog har Magten og Styrken.

Menneske-Aanden, det er et Ord, Som ingen af os kan udgrunde;

Menneske-Livet er dog dens Værk, Med Ordet i Menneske-Munde.

Menneske-Aanden, det er en Kraft, Som kan ikke selv sig forklare;

Men hvor den findes, i Raad og Daad

Kan Kraften sig klart aabenbare.

Sjæle og Kroppe i Tusindtal

Kan Menneske-Aanden forbinde,

Dem gjennemtrænge med Ord som Lyn,

Saa alle de et faar i Sinde. ${ }^{5}$

5. Poetiske Skrifter, ved Svend Grundtvig og Georg Christensen, VIII, s. 492-495. 
I talens gave har mennesket under faldets vilkår, under syndens og dødens herrevælde, i sin adskillelse fra Gud, al sandheds og alt livs kilde, bevaret en sans for sandhed og en længsel efter liv, som er al sand menneskeligheds inderste væsen og som sådan den uomgængelige forudsætning for menneskets frelse fra synden og døden. Menneske først - og kristen så.

I ethvert menneskeligt ord er der noget af sandhed, kærlighed og livskraft. I en af sine interessanteste theologiske afhandlinger, »Den guddommelige Treenighed" (i »Den kristelige Børnelærdom«) viser Grundtvig, at denne trehed af sandhed, kærlighed og livskraft $\mathrm{i}$ det levende menneskelige ord svarer til de tre guddomsnavne i Treenigheden: livskraften til Helligånden, sandheden til Sønnen og kærligheden til Faderen. ${ }^{6}$

$\mathrm{Nu}$ er den i ethvert menneskeligt ord boende sandhed, kærlighed og livskraft ikke uden videre ét med den sandhed, kærlighed og livskraft, som bor i Guds frelsende ord i Jesus Kristus, og stammer dog fra Gud og viser hen til ham.

I og gennem ethvert levende sprog, et modersmål, der kommer fra hjertet og går til hjertet, er det den sandhed; kærlighed og livskraft, der kommer fra Gud Skaberen og finder sin vej til menneskets ånd og krop, der gør det til et sandt menneske. Dette menneske er en synder - det er for Grundtvig indiskutabelt - men en menneskelig synder, ikke et dyr og ikke en djævel. Og at synderen er menneske, indebærer, at han kan høre og fæste lid til et ord, som overbeviser ham om hans skyld, og som tilgiver ham hans synd, hvis et sådant ord skulle lyde til ham. Dette menneske er også dødeligt, ja vel, men et dødeligt menneske, der som menneske kan høre og fæste lid til et ord, der overbeviser ham om hans trang til evigt liv, og som tilbyder ham et evigt liv, hvis et sådant ord skulle lyde til ham. Selv kan han ikke tale et sådant ord. Heller ikke kan noget andet menneske tale det. Men han og ethvert andet menneske kan - hvad en djævel eller et dyr aldrig vil kunne, fordi de ikke er skabt dertil (dyrene) eller har tabt muligheden derfor (djævlene) - høre et sådant ord, hvis Gud skulle tale det til dem, fordi de er sådan skabt, at de selv kan tale ord, der indeholder noget af sandhed, kærlighed og livskraft. Gud vil kunne tale til dem $i$ det sprog, de selv taler.

6. Udvalgte Skrifter ved Holger Begtrup, IX, S. 471-479. 
Det sprog, mennesker taler, er imidlertid altid et bestemt sprog, forskelligt fra andre bestemte sprog, et modersmål. Et universalsprog findes ikke som levende tale. Universalsprog som latin eller esperanto er ikke levende, men henholdsvis et dødt og et kunstigt sprog. Hvis jeg låner et levende sprog, et andet folks modersmål, f.eks. engelsk, for at gøre mig forståelig for ikke-danske mennesker, bliver engelsk ikke derved mit modersmål, selv ikke om jeg var i stand til at tale det »perfekt«. Sprogligt begavede menneskers "perfekte " brug af et fremmedsprog er som regel det, der stærkest afslører, at det talte fremmedsprog ikke er deres modersmål. Det sprog, hvori menneskelig sandhed, kærlighed og livskraft kan finde vej fra mit til et andet menneskes hjerte, er mit danske modersmål. Det udelukker naturligvis ikke, at vi kan have menneskeligt fællesskab med dem, der ikke taler vort eget sprog. Vi kan også have gudstjenesteligt fællesskab med dem på et for os fremmed sprog. Men det betyder, at dette kun kan ske i det omfang, vi lever i og af vort eget modersmål som en åndelig magt, hvorigennem sandhed, kærlighed og livskraft gennemtrænger vor ånd og krop og gør os til virkelige mennesker. Det er en kendt sag - hvad Grundtvig selv er et ypperligt eksempel på - at det, der gør den sprogkyndige til en god oversætter, i første række er det forhold, hvori han står til sit eget modersmål, langt mindre end hans leksikalske, grammatiske og semantiske indsigt i det fremmede sprog. Det sidste er naturligvis nødvendigt, da ingen kan oversætte, hvad han ikke forstår. Men når det kommer til selve oversættelsen, er det ikke indsigten i det fremmede sprogs opbygning, men den levende fortrolighed med modersmålet, det kommer an på.

Al skabt menneskelighed - til forskel fra den genløste, evige menneskelighed - er folkelig bestemt.

Folket er en åndelig virkelighed, grundlagt på summen af den menneskelige sandhed, kærlighed og livskraft, som det pågældende folks modersmål kan udtrykke.

At virkeliggøre sin egen sande menneskelighed, at blive "sandt menneske«, er at udfolde sin menneskelighed i et åndeligt fællesskab inden for et bestemt folk med et bestemt modersmål. Dette åndelige folkefællesskab bliver til ved brugen af et levende ord på modersmålet, et ord, der åbenbarer den åndelige magt, der er betroet dette folk af Skaberen, og som selv udløser bedrifter, der 
er den legemlige tilsynekomst af de åndelige kræfter, sandhed, kærlighed og livskraft, som dette folk har fået givet at sætte ind i slægtens samlede levnedsløb, »folkeånden«, som Grundtvig udtrykker sig.

Menneske først - og kristen så! Det betyder også dette: da Guds ord til sit folk, som det lyder på det af ham valgte sted, i menighedens forsamling omkring døbefont og nadverbord, altid udtales af et menneske, og da intet menneske har mere end ét modersmål, i hvilket sandhed, kærlighed og livskraft kan helt trænge ind $\mathrm{i}$ hans hjerte, lyder Guds ord til mennesker i menigheden altid på et folks modersmål. Selve det, at Gud stifter fællesskab mellem sig og mennesker gennem et ord på menneskesprog, medfører et bestemt forhold mellem menighed og folk. Guds ord, som er den hellige almindelige kirkes modersmål, må så at sige låne den sandhed, kærlighed og livskraft, der bor i det enkelte modersmål, for at bringe Guds sandhed, kærlighed og livskraft til menneskehjerter i det pågældende folk.

Menneske først og kristen så - betyder, at det enkelte folks åndelige liv, fremtrædende i dets levende brug af modersmålet, der alene kan gøre mennesketale og menneskehandlen ægte menneskelig, er den jordbund, hvori den kristne menighed må plantes og gro, hvis den ikke skal visne og dø.

Men hvad sker, hvis den enkelte og folket fornægter sin skabte menneskelighed ved at berøve sproget dets sandhed, kærlighed og livskraft? Et sådant misbrug af sproget er nemlig muligt. Ja, da mister den enkelte, da mister folket sin menneskelighed, umenneskeliggøres, dæmoniseres:

Sjæle og Kroppe med Folkemund, Som trodse med Ordet mod Aanden, De glemme dem selv som Menneske-Børn Og blive til Dyr efterhaanden.

Fugle og Fiske og vilde Dyr

Da fødes i Menneske-Hammen;

Og Stene maa græde, naar Folk som Fæ

Da vil lægge Hoveder sammen. 
Menneske-Livet er underligt

For Menneske selv som for Myre;

Men Dyre-Livet i Menneske-Ham,

Det er et forhekset Uhyre. ${ }^{7}$

En sådan dæmonisk forvrængning af sproget kan ske på mange måder. Oftest finder den vel sted i det politiske liv, når det levende ord på modersmålet, hvorved folkeånden skaber ægte historie, erstattes af kynisk propaganda, hvor løgn, had og livsødelæggelse erobrer ordet.

Hvor den skabte menneskelighed i den enkeltes og i folkets liv dæmonisk forvrænges, drives Guds ord og Jesu Kristi menighed, troens og håbets og kærlighedens kristelige liv, på flugt.

Menneske først og kristen så - betyder derfor, at menneskers frie tro på Gud og hans eenbårne Søn Jesus Kristus og deres frie kærlighed til Gud og hans folk, deres frie håb om deres eget livs oprejsning til evighed i gudmennesket Jesus Kristus, har sin uundværlige forudsætning i deres egen vedkenden sig deres sande menneskelighed i det jordiske liv, førend de møder Guds ord i Jesus Kristus, førend evangeliet om deres menneskeligheds genløsning i Jesus Kristus prædikes for dem. Kun når de vedkender sig deres egen skabte menneskelighed ved at give rum for ethvert menneskeord, som bringer sandhed, kærlighed og livskraft ind $\mathbf{i}$ deres tilværelse, bliver deres modtagelse af Guds ords sandhed, kærlighed og livskraft virkelig fri, i ægte tro, håb og kærlighed, og ikke tvang eller hykleri.

Stræbe da hver paa denne Jord

Sandt Menneske at være

Aabne sit Øre for Sandheds Ord,

Og unde Gud sin Ære;

Er Christendom da Sandheds Sag

Om Christen ei han er i Dag

Han bliver det i Morgen! ${ }^{8}$

7. Poetiske Skrifter, ved Svend Grundtvig og Georg Christensen, VIII, s. 495.

8. Grundtvigs Sangværk, Samlet Udgave, III, s. 298. 
Dette slutningsvers i digtet »Menneske først og Christen saa «iser forbavsende nok, at Grundtvigs orthodokse og kirkelige kristendom er mere ægte verdslig, mere virkelig jordbunden, end størstedelen af den moderne sækulartheologi.

For hvad har nu disse grundtvigske tanker at sige den kristne theolog, der som theolog engagerer sig i vor tids politiske opgør?

De siger ham, at han i sit politiske engagement overhovedet ikke skal være kristen, men menneske, og at han derfor ikke som theolog kan engagere sig politisk. Han kan det kun som det menneske, også en kristen theolog er, før og efter han bliver kristen, før og efter han arbejder theologisk. Dette ved han, hvis han er en god theolog.

Det politiske livsområde ligger inden for den skabte menneskeligheds grænser. Det hører til »menneske først«, ikke til »kristen så«. I al dens tilstræbte modernisme og fremskridtsvilje er moderne sækulartheologi for så vidt i sit væsen meget gammeldags. Det gammeldags ved den ligger i dens stærke interesse for at finde en theologisk eller kristelig begrundelse for en socialistisk politik, eller deri, at den søger at ægge kristne til politisk engagement ved argumenter, der appellerer til deres kristendom, i stedet for ved argumenter, der appellerer til deres menneskelighed. Denne indstilling er intet andet end en silde variant af den middelalderlige theokratiske samfundsforståelse. Det middelalderlige theokratiske samfunds kristne politik og moderne theologis politiske kristendom er tvillinger. Begge fornægter, omend hver på sin måde, »menneske først $\ll$.

På dette punkt er Grundtvigs kristendom også en udfordring til moderne theologi. Den siger ja til de unge theologers engagement i kampen for et retfærdigt og menneskeligt samfund. Denne kamp var også Grundtvigs $i$ hans tid og på denne tids vilkår. Havde Grundtvig levet i dag, ville han sikkert have set med sympati på den neo-marxistiske ungdom. Han ville sikkert gerne have holdt skole med dem, selv om han ikke ville have haft let ved at anerkende kirkefællesskabet med deres theologiske hedsporer - dog alt under den forudsætning, at de delte den "mosaisk-kristelige anskuelse af menneskelivet« (ikke at forveksle med den kristne tro), nemlig at mennesket er et åndeligt væsen og derfor kun kan og må vindes ved det frie ord, ikke knægtes ved vold. Men jeg tror også, at han i skolen ville møde dem med dette spørgsmål: 
»Ved I nu også, hvad sand retfærdighed og menneskelighed er?« Til de theologiske neo-marxister ville han måske sige: »Kommer al jeres iver for at engagere kirken (og ikke folket i dets helhed) i den sociale politik ikke af jeres egen mangel på interesse for den skabte menneskelighed som sådan, den, som I jo deler med alle ikke-kristne? Mangler I ikke også respekt for den ægte socialisme og dens rent saglig-verdslige begrundelse, når I er så optaget af at »forbedre« den med kristelighed og »theologi«? «

Grundtvigs kristendom er en udfordring til den moderne politiske theologi, fordi hans "menneske først « kalder disse theologer bort fra enhver form for theokrati, fra politisk kristendom og kristelig politik, fra al iver for at engagere specielt »kirken « $i$ det politiske liv, idet den stiller dem over for et kald til at bruge al deres politiske lidenskab og energi ikke på at politisere kirken, men på at menneskeliggøre samfundet. I den sidstnævnte bestræbelse har kirken ingen særlig plads, kan ikke få det. Derfor kan i ægte socialisme kirken ikke føjes ind i systemet eller blive »nødvendig « for dets virkeliggørelse, ja, ikke engang nyttig. Derfor har en sådan politik ikke brug for theologer som theologer, men kun for mennesker, hvoriblandt også theologer findes, som politikere. Ved de pågældende theologer det ikke selv, vil politikerne nok før eller siden sige dem det. "Bruge « theologerne - nemlig til propaganda - kan kun et allerede velbjerget »socialistisk « diktatur. Den rolle er ikke eftertragtelsesværdig.

Er moderne revolutionær socialisme af den type, der drager den theologiske ungdom i dag, ægte menneskelig i sine mål og midler? Eller står også den i fare for politisk dæmonisering? Menneske først! Theologien og kristendommen behøver vi ikke i kampen for politisk reform. Der trænger vi til menneskelighed, hvad enten den findes hos kristne eller ikke-kristne, theologer eller ikketheologer.

Egte menneskelighed giver sig til kende i et menneskeligt ord som sandhed, kærlighed, livskraft, både i det enkelte menneskes og i folkenes historie.

Derfor er Grundtvig en udfordring til moderne theologi frem for alt ved den måde, hvorpå han forstår at sondre mellem skabt og genfødt, jordisk og evigt liv, mellem folk og menighed, mellem politik og tro, sondre dem i sin redelige tanke for at forene dem, således sondrede, i sin egen tilværelse som dansk og kristen. 
Hvis denne sondring gennemføres klart og redeligt, da forbliver kristendommen ægte (orthodoks, kirkelig) kristendom: Kun ved badet og ved bordet hører vi Guds ord til os. Men da forbliver også menneskelivet, på tilsvarende måde, ægte menneskeligt, altomfattende, fælles for kristne og ikke-kristne, der deler med hinanden samme skabte menneskeliv, uanset hvilke religiøse begreber de måtte anvende derom. (Det er de kristne, der taler om det som skabt. De, der ikke deler den kristne skabelsestro, kan godt, ved deres respekt for sandhed, kærlighed og livskraft, ved deres anerkendelse af den grænse, deres skyld og død sætter for dem, leve det som skabt). »Menneske først og kristen så«.

Hvis sondringen gennemføres ret, er vejen banet for en menneskelig kristendom, d.v.s. en kristen tro, håb og kærlighed, der er en helt fri sag, kun båret af ordets sandhedsmagt, ikke fordret af statens bud eller fremmet af nogen menneskelig interesse, som den skal »tjene«, og for en kristen menneskelighed, det vil sige et menneskeliv, der forbliver menneskeligt og derfor frit kan åbne sig for kristendommen og frit afvise den, når evangeliet frit forkyndes.

Det redeligt sondrede kan forenes i frihed. Det uredeligt sammenblandede knægter både kristendommens og menneskets frihed.

Det er vel $\mathrm{i}$ en kort sammenfatning Grundtvigs udfordring til moderne theologi, især den form af moderne theologi, som er ude på at sammensmelte politik og kristendom, og som derfor står $\mathrm{i}$ fare for at glemme sondringen. 